University of Nebraska - Lincoln

DigitalCommons@University of Nebraska - Lincoln

Faculty Publications from the Harold W. Manter Laboratory of Parasitology

10-1993

\title{
Host Specificity of Calyptospora funduli (Apicomplexa: Calyptosporidae) in Atheriniform Fishes
}

John W. Fournie

United States Environmental Protection Agency, fournie.john@epa.gov

Robin M. Overstreet

Gulf Coast Research Laboratory, robin.overstreet@usm.edu

Follow this and additional works at: https://digitalcommons.unl.edu/parasitologyfacpubs

Part of the Parasitology Commons

Fournie, John W. and Overstreet, Robin M., "Host Specificity of Calyptospora funduli (Apicomplexa: Calyptosporidae) in Atheriniform Fishes" (1993). Faculty Publications from the Harold W. Manter Laboratory of Parasitology. 443.

https://digitalcommons.unl.edu/parasitologyfacpubs/443

This Article is brought to you for free and open access by the Parasitology, Harold W. Manter Laboratory of at DigitalCommons@University of Nebraska - Lincoln. It has been accepted for inclusion in Faculty Publications from the Harold W. Manter Laboratory of Parasitology by an authorized administrator of DigitalCommons@University of Nebraska - Lincoln. 


\title{
HOST SPECIFICITY OF CALYPTOSPORA FUNDULI (APICOMPLEXA: CALYPTOSPORIDAE) IN ATHERINIFORM FISHES
}

\author{
John W. Fournie and Robin M. Overstreet* \\ U.S. Environmental Protection Agency, Center for Marine and Estuarine Disease Research, \\ Gulf Breeze, Florida 32561
}

\begin{abstract}
Calyptospora funduli has a broad host specificity, infecting at least 7 natural and 10 additional experimental definitive hosts, all atheriniform fishes within 5 families, but most in the genus Fundulus. Barriers, apparently innate ones, prevent any development of $C$. funduli in perciform fishes but allow incomplete or abnormal development of the parasite in a few unnatural atheriniform hosts. In the freshwater species Fundulus olivaceus and Fundulus notti, these abnormalities consisted of asynchronous development, degeneration of the parasite in early stages of development, and the formation of numerous macrophage aggregates. Rivulus marmoratus has the ability to eliminate infections with a granulomatous inflammatory response. Additional barriers that limit natural infections of $C$. funduli in other hosts include feeding behavior, environmental conditions, and geographic isolation.
\end{abstract}

Calyptospora funduli has a broad host specificity. Narrow host specificity characterizes most members of the genus Eimeria, species having oocysts superficially similar to those in the genus Calyptospora. Members of Eimeria in homoiothermic hosts rarely infect more than 1 host genus (Joyner, 1982). Closely related species of homoiotherms may serve as susceptible hosts, but cross-transmission of the apicomplexans among such host genera and among families seldom occurs (Marquardt, 1981). In fact, some eimerians considered to infect more than 1 host species actually represent more than 1 species (Stockdale et al., 1979). Such generalities concerning host specificity of members of Eimeria infecting homoiothermic hosts do not necessarily apply to piscine eimerians and those infecting other poikilothermic species. In fishes, as well as amphibians and reptiles, species infecting more than 1 host are common. At least 14 piscine eimerians naturally infected 3 or more host species (Pellérdy, 1974; Dyková and Lom, 1981; Overstreet et al., 1984). This broad host specificity of many piscine coccidians is known from both intestinal and extraintestinal forms. Actually, C. funduli, the subject of the paper, and some other coccidians of poikilothermic hosts appear in some aspects more similar to sarcocystids, several of which have broad host specificity, than to members of Eimeria.

We report here natural and experimental definitive hosts for C. funduli, the most such hosts

Received 30 September 1992; revised 29 April 1993; accepted 13 May 1993.

* Gulf Coast Research Laboratory, P.O. Box 7000, Ocean Springs, Mississippi 39564. known for any piscine coccidian; development of the parasite in atypical hosts (those not naturally infected or rarely infected); and prevalence of the infection of the coccidian in Menidia beryllina, a natural but probably infrequent host.

\section{MATERIALS AND METHODS}

Fishes used in this study were caught with minnow traps, cast nets, and dip nets from coastal Mississippi: Halstead Bayou and Fourmile Branch of Moungers Creek in Jackson County; Tchoutacabouffa River in Harrison County. Grass shrimp (Palaemonetes pugio) were collected with dip nets from the small boat harbor at the Gulf Coast Research Laboratory, Ocean Springs, Mississippi.

Grass shrimp were infected experimentally by individually feeding them sporulated oocysts of $C$. funduli in the liver of wild Fundulus grandis. Fishes were infected by feeding them pieces of cephalothorax from experimentally infected grass shrimp, either individually or in groups of 6-10, depending on the test.

To determine if fishes other than the most common hosts, F. grandis, Fundulus similis, Fundulus heteroclitus, and Fundulus pulvereus, were naturally infected with $C$. funduli, up to 20 individuals of the following fishes were examined from Halstead Bayou where the parasite was endemic: Fundulus jenkinsi, Cyprinodon variegatus, Menidia beryllina, Gambusia affinis, Adinia xenica, Poecilia latipinna, and Dormitator maculatus. Livers from these fishes were examined with a compound microscope as fresh squash preparations.

To determine if infections with $C$. funduli can be acquired readily by cyprinodontid fishes other than the 4 common hosts and by noncyprinodontid fishes, we fed 17 fish species the cephalothorax from experimentally infected grass shrimp. Anywhere from 1 to 8 individuals of each of those species were fed shrimp, depending on availability of specimens. Livers from representatives of those fish were examined for the parasite 20 days after being administered infective sporozoites (hereafter termed postinfection, PI). If infections were produced by that time and if extra fish were available, additional specimens were examined at a later date to determine if sporulation had occurred. We 
TABLE I. Piscine hosts for Calyptospora funduli.

\begin{tabular}{|c|c|c|}
\hline $\begin{array}{l}\text { Naturally } \\
\text { infected }\end{array}$ & $\begin{array}{c}\text { Experimentally } \\
\text { infected }\end{array}$ & $\begin{array}{l}\text { Unable to infect } \\
\text { experimentally }\end{array}$ \\
\hline $\begin{array}{l}\text { Fundulus grandis } \\
\text { Fundulus similis } \\
\text { Fundulus pulvereus } \\
\text { Fundulus heteroclitus } \\
\text { Fundulus jenkinsi } \\
\text { Fundulus confluentus } \\
\text { Menidia beryllina }\end{array}$ & $\begin{array}{l}F . \text { grandis }(200)^{*} \\
F . \text { similis }(100) \\
F . \text { heteroclitus }(60) \\
\text { Fundulus parvipinnis }(2) \\
\text { Fundulus chrysotus }(12) \dagger \\
\text { Fundulus notti }(24) \dagger \\
\text { Fundulus olivaceus }(38) \dagger \\
\text { Cyprinodon variegatus }(4) \\
\text { Rivulus marmoratus }(5) \dagger \\
\text { M. beryllina }(24) \\
\text { Poecilia latipinna }(8) \dagger \\
\text { Poecilia reticulata }(6) \\
\text { Oryzias latipes }(6)\end{array}$ & $\begin{array}{l}\text { Pimephales promelas (8) } \\
\text { Notropis maculatus (2) } \\
\text { Lepomis macrochirus (4) } \\
\text { Dormitator maculatus (2) }\end{array}$ \\
\hline
\end{tabular}

* Number of fish fed infective tissue is indicated in parentheses.

† Hosts that exhibited some abnormal coccidian development, other than inhibited maturation, plus atypical host response.

found that these fish were acceptable for experimental purposes by the lack of established sporulated organisms in specimens examined at day 20 and by the lack of any infections in additional specimens examined from the collection site. Histologic sections of some of those livers in test animals were prepared and examined to determine if the host response was more extensive in atypical hosts than in common natural hosts.

To assess the development of $C$. funduli in potentially atypical hosts, we closely followed experimental infections in Fundulus notti and Fundulus olivaceus and compared them with simultaneous infections in $F$. grandis and $F$. similis. Liver from $F$. notti was prepared for histological examination at days $5,11,15$, $18,20,25,28,32,34,40,46$, and 50 PI, whereas liver from $F$. olivaceus was examined at days $5,10,15,18$, 20, 23, 25, 28, 32, 40, and 46 PI. Development of $C$. funduli was also followed in several other potentially atypical hosts, including 2 specimens of $P$. latipinna, 4 specimens of Fundulus chrysotus, and 5 specimens of Rivulus marmoratus. In all cases, a portion of the liver was examined in fresh squash preparations, and the remaining portion was fixed in Bouin's solution for histologic examination.

To determine the prevalence of infections with $C$. funduli in a potentially atypical host, we examined 223 specimens of $M$. beryllina from endemic bayous, Mississippi Sound, and associated barrier islands. Infections were related to host length. Livers were all examined by fresh squash preparations, and portions of all infected livers were fixed in $10 \%$ buffered formalin or Bouin's solution for histologic examination.

Livers were dehydrated in a graded series of ethanol, cleared in a commercial clearing agent, and embedded in paraffin. Sections of livers were cut at $6 \mu \mathrm{m}$ and stained using Harris' hematoxylin and eosin or the Armed Forces Institute of Pathology's method for lipofuscin, a product of oxidation and polymerization of unsaturated lipids (Luna, 1968).

\section{RESULTS}

Atheriniform fishes other than the 4 species of Fundulus reported by Solangi and Overstreet
(1980) can serve as natural definitive hosts for $C$. funduli (Table I). Infections occurred in a relatively high percentage of $F$. pulvereus (31\%, 21 of 67 examined) and $F$. jenkinsi (37\%, 15 of 41 ), whereas only a relatively few individuals of $M$. beryllina (3\%, 6 of 223) and Fundulus confluentus $(8 \%, 1$ of 12$)$ harbored infections. Rather than progressing synchronously as development ensued in common hosts, infections in several cases in all 4 host species exhibited asynchronous development, and some of those had many degenerating stages (Fig. 1). Degeneration in uncommon hosts as defined here consisted of malformed stages and the dissolution of sporonts and sporocysts that involved more than approximately $50 \%$ of the organisms.

Thirteen species of fish were experimentally infected with $C$. funduli (Table I). These fishes included representatives of 6 genera and 5 families, all of which are members of the order Atheriniformes: Cyprinodontidae (killifishes; Fundulus spp. and $C$. variegatus), Aplocheilidae (mangrove rivulus; $R$. marmoratus), Poeciliidae (livebearers; Poecilia spp.), Adrianichthyidae (medaka; Oryzias latipes), and Atherinidae (inland silverside; $M$. beryllina). Infections failed to develop in the 4 tested members from the order Perciformes.

We observed sporulated oocysts in $F$. grandis, $F$. similis, $F$. heteroclitus, $F$. notti, $F$. olivaceus, $R$. marmoratus, $C$. variegatus, Poecilia reticulata, and $M$. beryllina. Earlier stages occurred in fishes examined before 48 days PI (Table II). We observed incomplete development represented by unsporulated oocysts in $P$. latipinna, sporoblasts in $F$. chrysotus, macrogamonts in Fundulus parvipinnis, and merozoites in $O$. latipes. 

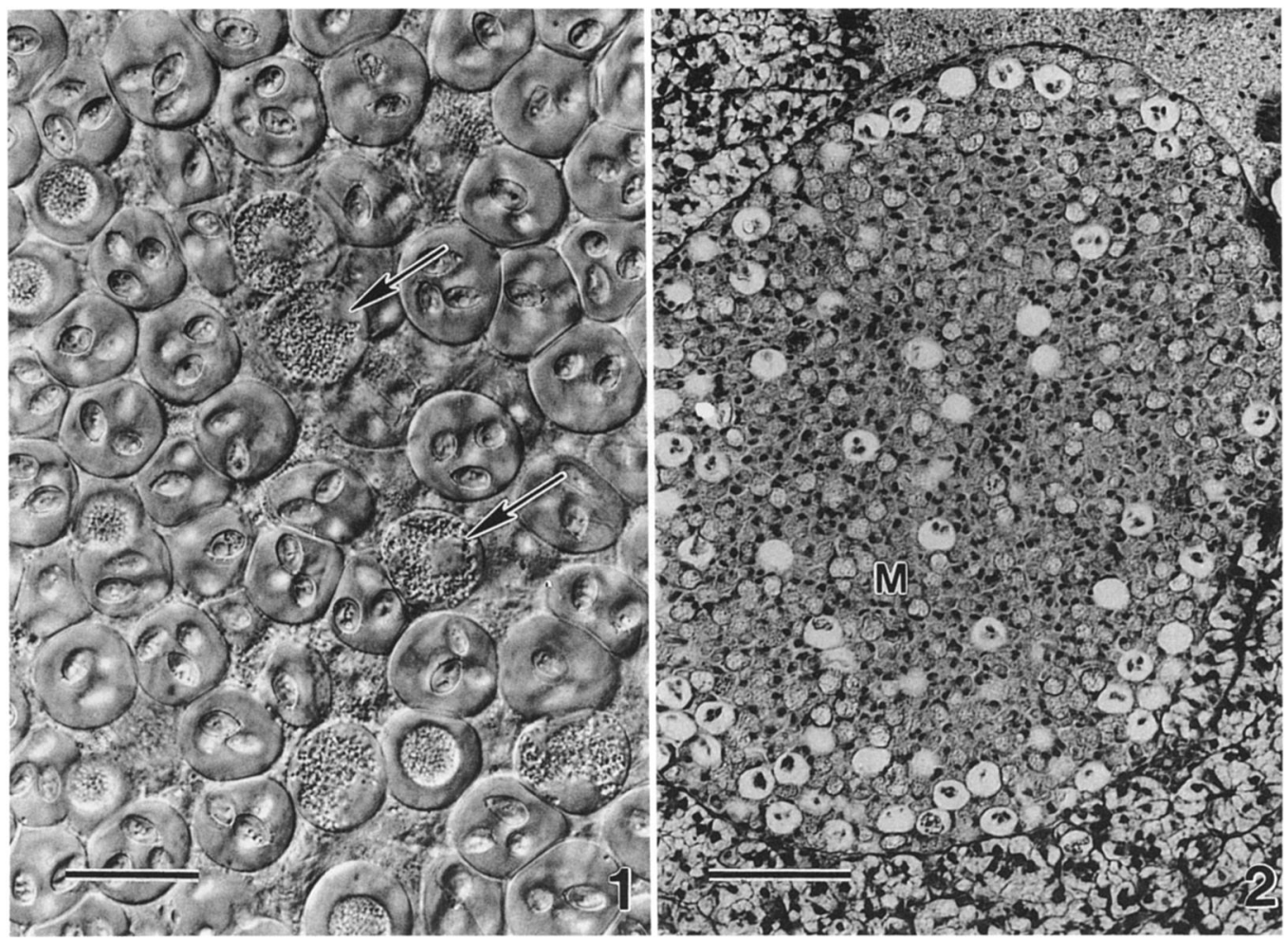

FIgUREs 1, 2. Degenerating infections of Calyptospora funduli in liver of Fundulus species. 1. Fresh squash preparation from natural infection in $F$. jenkinsi from Halstead Bayou, Ocean Springs, Mississippi, exhibiting asynchronous development with a few degenerating sporonts (arrows). Nomarski optics. Bar $=30 \mu \mathrm{m}$. 2. Section from the experimentally infected atypical host $F$. notti at day 25 postinfection, showing mature macrophage aggregate (M) containing developing oocysts. Hematoxylin and eosin stain. Bar $=75 \mu \mathrm{m}$.

At least 5 of the 13 atheriniforms that could be experimentally infected displayed abnormal development of the parasite (Table I). These abnormalities in atypical hosts affected more than $50 \%$ of the parasites and consisted of asynchronous development, malformed stages, and de- generation of the organisms in early stages of development. If the incomplete development in $F$. parvipinnis and $O$. latipes is included, the number is 7. Development of the parasite in $F$. chrysotus was abnormal and never observed beyond the daughter sporoblast stage; however,

TABLE II. Days postinfection when developmental stages of Calyptospora funduli were observed in 5 experimentally infected atypical fish hosts plus those in Fundulus similis as a typical control; all were maintained at 20-22 C.

\begin{tabular}{|c|c|c|c|c|c|c|}
\hline \multirow[b]{2}{*}{$\begin{array}{c}\text { Fish } \\
\text { species }\end{array}$} & \multirow[b]{2}{*}{$\begin{array}{l}\text { Number } \\
\text { examined }\end{array}$} & \multicolumn{5}{|c|}{ Days developmental stages first observed* } \\
\hline & & Merozoites & $\begin{array}{l}\text { Developing } \\
\text { oocysts }\end{array}$ & Sporoblasts & $\begin{array}{l}\text { Unsporulated } \\
\text { oocysts }\end{array}$ & $\begin{array}{l}\text { Sporulated } \\
\text { oocysts }\end{array}$ \\
\hline Fundulus similis $\dagger$ & $>21$ & $4-11$ & 13 & 21 & 28 & 35 \\
\hline Fundulus chrysotus & 15 & - & 26 & 33 & - & - \\
\hline Fundulus olivaceus & 38 & 10 & 20 & 23 & 28 & 40 \\
\hline Fundulus notti & 24 & 15 & 20 & 32 & 46 & 50 \\
\hline Poecilia latipinna & 8 & - & 20 & 33 & 50 & - \\
\hline Rivulus marmoratus & 5 & - & 20 & 34 & 47 & 60 \\
\hline
\end{tabular}

* Days for observations of different hosts were not necessarily identical.

† From Hawkins et al. (1984). 
sporulation occurred in the other 4 atypical hosts listed in Table II, developing most rapidly in $F$. olivaceus.

Some of the fishes with abnormal coccidian development exhibited more extensive host responses and pathological changes than those typically seen in infected $F$. grandis, $F$. similis, and $F$. heteroclitus. The mildest host response in an atypical host occurred in $F$. chrysotus. Histological sections of livers from $F$. chrysotus revealed no degenerating foci, but a moderate granulocytic inflammatory response still was present at 36 days PI, after sporoblasts had formed. A moderate host response occurred in both $F$. notti (Fig. 2 ) and $F$. olivaceus (Fig. 3), with many degenerating foci present in the hepatic parenchyma by days 25 and 28 PI, respectively. In some specimens of $F$. olivaceus, there were areas of extensive fibrous encapsulation (Fig. 4). Inflammatory cells surrounded some foci, and these consisted of degenerating parasites, degenerating hepatocytes, and macrophages. Such foci stained positively for lipofuscin. By days 40 and 46 PI, all infections in those 2 species, whether consisting of sporulated oocysts or not, lacked the inflammatory infiltrate and degenerating parasites.

The most extensive host response to $C$. funduli occurred in $R$. marmoratus. In fresh squash preparations of the host, approximately $95 \%$ of the parasites showed some degeneration by day 47 PI. Histologically, numerous necrotic foci with both degenerating parasites and host cells occurred in the hepatic parenchyma at days 20 and 26 PI. Inflammatory cells surrounded degenerating foci by day 34 PI (Fig. 5), and some small areas of exudate occurred in the liver. By days 47 and $60 \mathrm{PI}$, an extensive inflammatory infiltrate, including an influx of eosinophilic granular cells, surrounded the degenerating foci. Many of these foci had been invaded by macrophages, and the foci stained positively for lipofuscin. Granuloma formation was also apparent (Fig. 6).

Of the 6 naturally infected specimens of $M$. beryllina, all were mature individuals with a total length ranging from 81 to $112 \mathrm{~mm}$. That sizegroup consisted of 114 fish from a variety of endemic locations. One of those fish contained developing oocysts, and the parasite exhibited little or no degeneration. The other 5 exhibited sporulated oocysts, but all those infections exhibited some asynchronous development with many degenerating stages. Histologically, no unusual pathologic change was seen in any of the 6 natural infections.

\section{DISCUSSION}

The broad host specificity of $C$. funduli, including at least 7 natural definitive hosts and 13 experimental hosts, 10 of which differ from those 7 , is the most known for any coccidian. When compared with species of Eimeria in homoiothermic hosts, C. funduli has an exceptionally wide range of hosts because nearly all those species of Eimeria infect only 1 host species (Joyner, 1982). Such wide specificity for $C$. funduli, however, is not unexpected because multiple hosts are reported for many coccidians infecting fish and other poikilothermic hosts (Dyková and Lom, 1981; Overstreet, 1981). Additionally, some of the accepted generalities concerning host specificity applicable to eimerians infecting homoiothermic animals may not apply to those in fish. As pointed out by Marquardt (1981), we need to examine the ability for Eimeria species and sarcocystids, which have sporocystic plates and also are heteroxenous like $C$. funduli, to signal the host cell so that it can function as necessary for the parasite to be accepted, live, and develop. Calyptospora funduli can be used to investigate the problem. Even though sporulated oocysts developed in the liver of at least 5 of the experimental atypical fish hosts, we noted anywhere from 50 to $95 \%$ of the oocysts in those fish to be degenerating. Seldom did we see more than a few degenerating oocysts in well adapted natural hosts such as $F$. grandis. Nevertheless, the highest number of reported definitive hosts for a sarcocystid is the 6 feline species that host Toxoplasma gondii. Virtually any homoiotherm and some cold-blooded vertebrates can serve as an intermediate host for that species (Smith, 1981). Other sarcocystids have 5 or possibly 6 mostly canine or snake species acting as definitive hosts (Levine, 1988). Calyptospora funduli also has many species of potential intermediate hosts, but they all apparently have to be palaemonid shrimps (Fournie and Overstreet, 1983).

Three barriers limit infections of $C$. funduli, and they are the host, environmental conditions, and geographic separation. First, presently undefined innate barriers serve as primary blocks. These would account for the inability of $C$. funduli to develop in the 4 perciform fishes tested and the incomplete or abnormal development in 5 of 13 experimentally infected atheriniforms. We have examined the liver of numerous specimens of more than 100 local fish species for either specific parasites or a general examination 

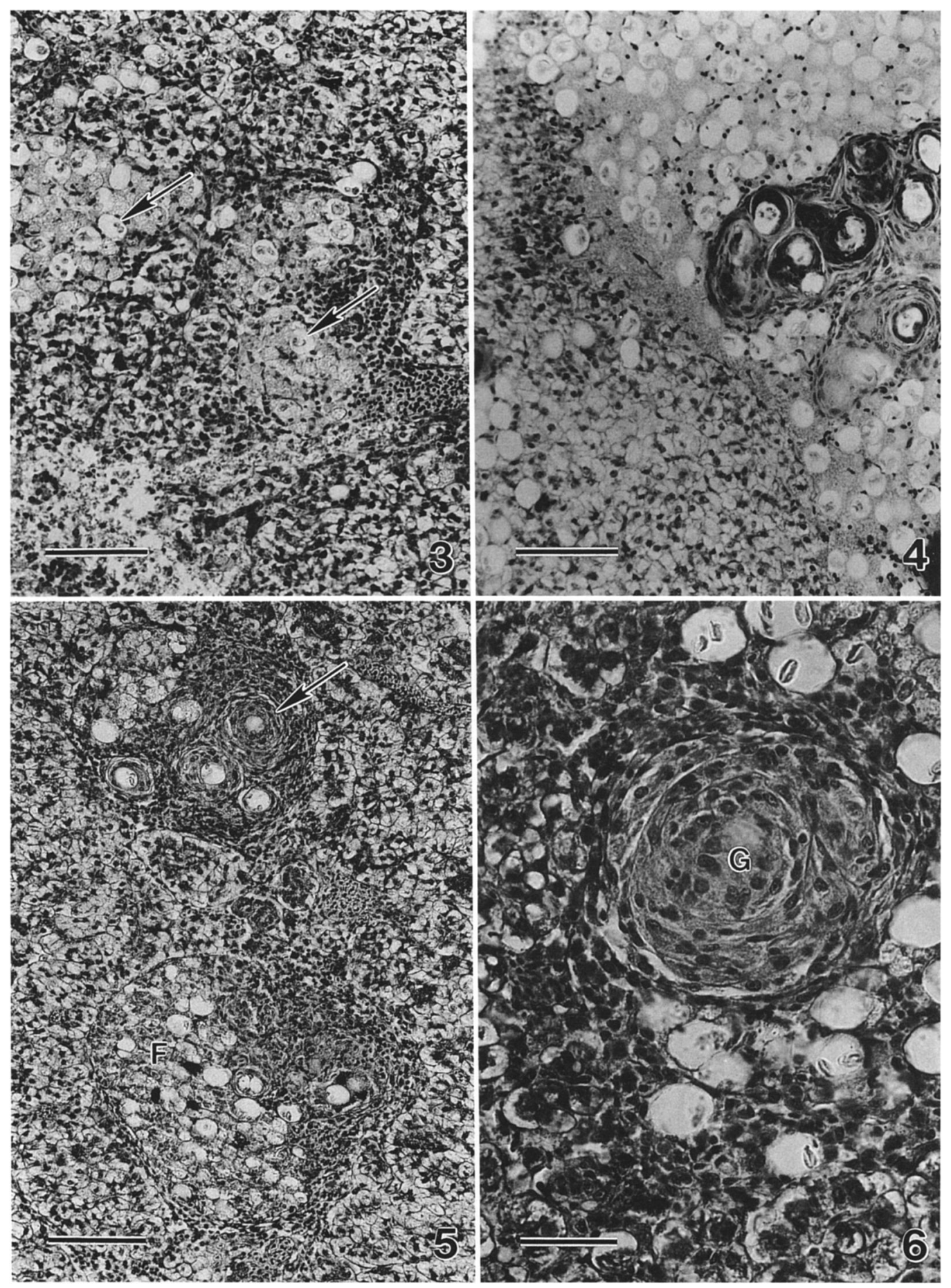

FIGURES 3-6. Photomicrographs of sectioned livers of experimentally infected atypical hosts for Calyptospora funduli, hematoxylin and eosin stain. 3. Degenerating foci in Fundulus olivaceus at 28 days postinfection (PI). Note oocysts (arrows). Bar $=75 \mu \mathrm{m}$. 4. Fibrous encapsulation of parasites and adjacent exudate in $F$. olivaceus at day 25 PI. Bar $=70 \mu \mathrm{m}$. 5. Focus of degenerating oocysts $(\mathrm{F})$ and initial granuloma formation (arrow) in Rivulus marmoratus at 34 days PI. Bar $=75 \mu \mathrm{m}$. 6. Close-up showing a more developed, typical, small, epithelioid granuloma $(\mathrm{G})$ in $R$. marmoratus at 60 days PI. Bar $=30 \mu \mathrm{m}$. 
without finding any other natural nonatheriniform infections.

Pathological alterations often indicate a poor host-parasite association, and the course of extraintestinal fish coccidiosis is inadequately known. It is best understood for C. funduli (e.g., Solangi and Overstreet [1980], Hawkins et al. [1981], Solangi et al. [1982], Vogelbein et al. [1987]), but pathological alterations are also reported for a few other infections such as $C$. serrasalmi in the liver of Serrasalmus niger (see Cheung et al., 1985), Eimeria sp. in the liver of Micromesistius poutassou (see MacKenzie, 1981), Goussia deguistii in the spleen and elsewhere of cyprinids (Paterson and Desser, 1982), Eimeria scardinii in the kidney of Rutilus rutilus (see Athanassopoulou-Raptopoulou and Vlemmas, 1986), and Goussia spraguei in the kidney of Gadus morhua (see Morrison and Poynton, 1989a) and Melanogrammus aeglefinus (see Morrison and Poynton, 1989b).

Infections of $C$. funduli follow a specific sequence in well adapted $F$. grandis and other examined natural hosts (Solangi and Overstreet, 1980), with the host response apparently unable to eliminate the moderate to extensive infections often seen in both naturally and experimentally infected fish. It follows a specific sequence because development of the coccidian under typical conditions is synchronous, and the host responds differently to the different parasitic stages. The first histological indication of the cellular response in $F$. grandis occurs at about day 10 at 22-25 C when a few inflammatory cells randomly infiltrate the liver. By day 18 , numerous leukocytes, including lymphocytes, monocytes, heterophils, and eosinophils accumulate around some gamonts (Hawkins et al., 1981); probably most of this accumulation is in response to cellular damage from extensive invasion of merozoites into host cells. Simultaneously, an abundance of fibroblasts and perisinusoidal cells lay down collagen around small aggregates of gamonts. By day 20, the leukocytic infiltrate diminishes, and it is no longer apparent by day 30 . The number of oocysts in heavily infected fish apparently is not significantly influenced; the response to the parasite appears to be most effective in lightly infected hosts. Natural infections often demonstrate various degrees of pigmentation associated with infections.

In some experimentally infected atypical hosts in which development of $C$. funduli was abnormal, the host response did not follow the se- quence described for infections in the estuarine $F$. grandis. For example, in the 2 freshwater killifishes $F$. notti and $F$. olivaceus, numerous foci comprising both degenerating parasites and degenerating hepatocytes occurred in the hepatic parenchyma, and many of these foci had been infiltrated by macrophages. These histological findings are consistent with the observation that approximately $50 \%$ of the parasites in fresh squash preparations of infected liver from those 2 species showed degeneration.

In the species with the most extensive host response, $R$. marmoratus, approximately $95 \%$ of the parasites exhibited degeneration by day 47 PI in fresh squash preparations of infected liver. The intense cellular inflammatory response, the occurrence of degenerating foci containing macrophages, and the extensive granuloma formation indicate that $R$. marmoratus produces significant innate barriers to the development of $C$. funduli. The occurrence of granulomas in the liver of $R$. marmoratus is consistent with the fact that this susceptible species apparently has the ability, at least partially, to eliminate fully developed specimens of $C$. funduli. Granulomas ultimately serve to protect the host from high local concentrations of foreign materials of both endogenous and exogenous origin (Adams, 1976). In both circumstances, the mononuclear phagocytes of the granuloma phagocytose and ultimately degrade the foreign material as completely as possible. Establishment of the basic epithelioid granulomatous inflammation typically associates with development of activated macrophages and protects the host against intracellular parasites (Adams, 1983). Vogelbein et al. (1987) provided more details on the infiltration of mononuclear cells recruited from the peripheral circulation during gamogamy in the $R$. marmoratus $-C$. funduli system and suggested that resulting macrophage aggregates were associated with macrogamont degeneration. Similarly, later development of granulomas was considered an inflammatory response to the oocysts.

One ecological barrier that plays an important role in limiting infections of $C$. funduli is feeding behavior. Menidia beryllina rarely exhibited natural infections of $C$. funduli, as indicated by the prevalence value of $2.7 \%$. This low prevalence of infection probably occurred because $M$. beryllina, the inland silverside, has a protrusible and tube-shaped mouth used for feeding on small crustaceans, and the fish apparently does not normally feed upon palaemonid shrimp (Darnell, 
1958; Kinch, 1979; McComas and Drenner, 1982). However, the species is an opportunistic omnivore, and as individuals get larger, they feed on larger prey (Dixon in Stickney and McGeachin, 1978), such as grass shrimp. Likewise, it was the large individuals, $5.3 \%$ of 114 fish $>80$ $\mathrm{mm}$, that had infections.

Another example of feeding behavior limiting $C$. funduli infections concerns the host $C$. variegatus. Natural infections of $C$. funduli were not seen in the 20 examined specimens of the sheepshead minnow from Halstead Bayou even though infections occurred concurrently in the 6 sympatric naturally infected species of Fundulus. Moreover, C. variegatus could be infected experimentally. Cyprinodon variegatus apparently does not feed on palaemonid shrimps, the intermediate hosts. Whether in a Florida marsh, Galveston (Texas) marshes, or local estuaries (Odum and Heald, 1972; Stickney and McGeachin, 1978; R. W. Heard, pers. comm., pers. obs.), this species, based on observations of several specimens from each locality, feeds on relatively small food items: detritus, foraminiferans, harpacticoid copepods, ostracods, various arthropod larvae, and fish eggs. We should emphasize that examination of up to 20 individuals of most of the following species, but $>35$ of $C$. variegatus and $M$. berylli$n a$, from Halstead Bayou where the parasite was endemic yielded no infections: $C$. variegatus, $M$. beryllina, G. affinis, A. xenica, P. latipinna, and D. maculatus.

Salt concentration can also serve a barrier to infection. In the few years previous to $1980, F$. grandis did not occur in the ponds and normally high-salinity lagoons of Horn Island, a barrier island about $20 \mathrm{~km}$ offshore from Mississippi, and it occurred there only irregularly before then. The more halophilic $F$. similis and palaemonid shrimps typically occurred there, but $C$. funduli never was observed in the occasional necropsies conducted on the fish over several years for a variety of reasons. Apparently following the temporary establishment of relatively low salinity water in Mississippi Sound and around the island, $F$. grandis and the infection showed up (Fournie and Solangi, 1980). Despite the salinity barrier of Mississippi Sound being reestablished, both $F$. grandis and $F$. similis still inhabited the island waters in 1992 and still exhibited infections. On the other hand, even though freshwater, estuarine, and marine palaemonid shrimps all can serve experimentally as intermediate hosts (Fournie and Overstreet, 1983), infections do not spread a few kilometers and become established in riverine habitats containing the same freshwater fish and shrimp species that we have infected experimentally.

Infections of $C$. funduli in $F$. heteroclitus were observed by us from coastal Massachusetts (northern record: New Bedford Harbor-Buzzards Bay, specimens provided by George $\mathrm{R}$. Gardner, U.S. EPA Environmental Research Laboratory, Narragansett, Rhode Island), Virginia, and Georgia and in other killifishes from various scattered locations in the northern Gulf of Mexico. Presumably, $C$. funduli has a wide geographic range in the coastal areas of the western North Atlantic Ocean, but it does not occur in the coastal areas of the Pacific Ocean where several palaemonid species occur, even though the common $F$. parvipinnis from California served as an experimental host. Gamonts formed in that host without any apparent abnormality, but because of a small number of available specimens, we did not have the opportunity to examine individuals in which more developed stages could have occurred.

The combination of the host-parasite's innate barriers, the environmental conditions, and geographic separation combine to influence the resulting host specificity and host response. Moreover, the added interaction of environmental conditions such as low temperature further influences these results (Solangi et al., 1982). Even though the fish hosts have both a cellular and humoral response, their parasites are not as buffered from environmental conditions as those in homoiothermic hosts. Consequently, more extreme cases of broad host specificity can be expected for coccidians in fishes.

\section{ACKNOWLEDGMENTS}

This study was conducted in cooperation with the U.S. Department of Agriculture, CSRS, grant no. 92-38808-6920. We acknowledge Jean Jovonovich Alvillar for printing the figures. This paper is contribution no. 809 of the U.S. Environmental Protection Agency, Environmental Research Laboratory, Gulf Breeze, Florida 32561.

\section{LITERATURE CITED}

ADAMS, D. O. 1976. The granulomatous inflammatory response. American Journal of Pathology 84: 163-192.

. 1983. The biology of the granuloma. In Pathology of granulomas, H. L. Ioachim (ed.). Raven Press, New York, p. 1-20.

Athanassopoulou-Raptopoulou, F., and J. VlemMAS. 1986. Eimeria scardinii Pellérdy and Mol- 
nár, 1968 in the kidneys of Rutilus rutilus (L.) and Scardinius erythrophthalmus (L.) from northern Greece. Journal of Fish Diseases 9: 411-416.

Cheung, P. J., R. F. Nigrelli, AND G. D. RugGieri. 1985. Calyptospora serrasalmi sp. nov. (Coccidia: Calyptosporidae) from liver of the black piranha, Serrasalmus niger Schomburgk. Journal of Aquariculture \& Aquatic Sciences 4: 54-57.

DARNELl, R. M. 1958. Food habits of fishes and larger invertebrates of Lake Pontchartrain, Louisiana, an estuarine community. Publications of the Institute of Marine Science, University of Texas 5: $353-416$.

DYková, I., AND J. LoM. 1981. Fish Coccidia: Critical notes on life cycles, classification and pathogenicity. Journal of Fish Diseases 4: 487-505.

FoURNIE, J. W., AND R. M. OverstreEt. 1983. True intermediate hosts for Eimeria funduli (Apicomplexa) from estuarine fishes. Journal of Protozoology 30: 672-675.

- AND M. A. Solangi. 1980. Prevalence of Eimeria funduli (Protozoa: Eimeriidae) in the longnose killifish Fundulus similis from Horn Island, Mississippi. Gulf Research Reports 6: 427428.

Hawkins, W. E., J. W. Fournie, and R. M. OvERSTREET. 1984. Intrahepatic stages of Eimeria funduli (Protista: Apicomplexa) in the longnose killifish, Fundulus similis. Transactions of the American Microscopical Society 103: 185-194.

- , M. A. SOlANGI, AND R. M. OVERSTREET. 1981. Ultrastructural effects of the coccidium, Eimeria funduli Duszynski, Solangi, and Overstreet, 1979 on the liver of killifishes. Journal of Fish Diseases 4: 281-295.

JOYNER, L. P. 1982. Host and site specificity. In The biology of the Coccidia, P. L. Long (ed.). University Park Press, Baltimore, Maryland, p. 35-62.

KINCH, J. C. 1979. Trophic habits of the juvenile fishes within artificial waterways-Marco Island, Florida. Contributions in Marine Science 22: 7790.

LEVINE, N. D. 1988. The protozoan phylum Apicomplexa, Vol. II. CRC Press, Inc., Boca Raton, Florida, $154 \mathrm{p}$.

LunA, L. G. 1968. Manual of histologic staining methods of the Armed Forces Institute of $\mathrm{Pa}$ thology, 3rd ed. McGraw-Hill, New York, 258 p.

MacKenzie, K. 1981. The effect of Eimeria sp. infection on the condition of blue whiting, Micromesistius poutassou (Risso). Journal of Fish Diseases 4: 473-486.

MARQUARDT, W. C. 1981. Host and site specificity in the Coccidia: A perspective. Journal of Protozoology 28: 243-244.

McComAs, S. R., AND R. W. DRENNER. 1982. Species replacement in a reservoir fish community: Silverside feeding mechanics and competition. Canadian Journal of Fisheries and Aquatic Sciences 39: 815-821.

Morrison, C., AND S. Poynton. 1989a. A new species of Goussia (Apicomplexa, Coccidia) in the kidney tubules of the cod, Gadus morhua L. Journal of Fish Diseases 12: 533-560.

, AND - 1989b. A coccidian in the kidney of the haddock, Melanogrammus aeglefinus (L.). Journal of Fish Diseases 12: 591-593.

Odum, W. E., AND E. J. HeAld. 1972. Trophic analysis of an estuarine mangrove community. Bulletin of Marine Science 22: 671-738.

OVERSTREET, R. M. 1981. Species of Eimeria in nonepithelial sites. Journal of Protozoology 28: 258260.

- , W. E. HAWkINS, AND J. W. FOURNIE. 1984. The coccidian genus Calyptospora $\mathrm{n}$. g. and family Calyptosporidae n. fam. (Apicomplexa), with members infecting primarily fishes. Journal of Protozoology 31: 332-339.

Paterson, W. B., and S. S. Desser. 1982. The biology of two Eimeria species (Protista: Apicomplexa) in their mutual fish hosts in Ontario. Canadian Journal of Zoology 60: 764-775.

Pellérdy, L. P. 1974. Coccidia and coccidiosis, 2nd ed. Akádemiai Nyomda, Budapest, Hungary, 959 p.

Smith, D. D. 1981. The Sarcocystidae: Sarcocystis, Frenkelia, Toxoplasma, Besnoitia, Hammondia, and Cystoisospora. Journal of Protozoology 28: 262-266.

Solangi, M. A., AND R. M. OverStreEt. 1980. Biology and pathogenesis of the coccidium Eimeria funduli infecting killifishes. Journal of Parasitology 66: 513-526.

,-- AND J. W. FouRNIE. 1982. Effects of low temperature on development of the coccidium Eimeria funduli in the Gulf killifish. Parasitology 84: 31-39.

Stickney, R. R., AND R. B. MCGEaChin. 1978. Food habits of fishes associated with marshland developed in dredged material. Proceedings of the Annual Conference Southeastern Association of Fish and Wildlife Agencies 32: 547-560.

Stockdale, P. H., G. B. Tiffin, G. Kozub, and B. Сhobotar. 1979. Eimeria contorta Haberkorn, 1971: A valid species of rodent coccidium. Canadian Journal of Zoology 57: 264-270.

Vogelbein, W. K., J. W. Fournie, AND R. M. OVERSTREET. 1987. Sequential development and morphology of experimentally induced hepatic melano-macrophage centres in Rivulus marmoratus. Journal of Fish Biology 31(Supplement A): 145-153. 